\title{
Experimental investigations on Thomson's law of wave-motion on water
}

\section{O. Riess}

To cite this article: O. Riess (1891) Experimental investigations on Thomson's law of wave-motion on water, Philosophical Magazine Series 5, 31:188, 71-74, DOI: 10.1080/14786449108620072

To link to this article: http://dx.doi.org/10.1080/14786449108620072

曲 Published online: 08 May 2009.

Submit your article to this journal $\sqsubset \pi$

Џ Article views: 2

Q View related articles $\sqsubset$ 
it from the Silurian plain of Nashville. The table-land is about 40 miles wide, and is intersected by the valley of the Sequachee River, running in a north-easterly direction along a subsidiary anticline from near Jasper for a distance of sixty miles.

From the base of the Cambrian beds, the whole Lower and Upper Palæozoic formations succeed each other in apparently conformable sequence, except at the junction of the Upper and Lower Silurian series, where a probable discordance occurs. The prolonged period of subsidence and deposition at length gave way to elevation; acting with the greatest effect along the Alleghanies. Under these circumstances, denudation preceded most rapidly along the tract bordering the Protaxis, whilst the synclines were protected from erosion to a greater degree; and as the elevatory morement was more rapid along the Unaka range, the flow of the streams was generally westward. At a later period the Cumberland plateau began to be formed by backward erosion of the strata in the direction of the dip; so that it owes its development to the erosion of the Tennessee and Clinch rivers on the one hand, and to the Cumberland river on the other. Where the Tennessee River flows in a north-westerly direction through the Cumberland plateau, the divide between it and the Gulf of Mexico is only 280 feet above the riverbed, whilst the table-land is 1400-1500 feet above. The author infers, therefore, that when the river began to erode its channel the plateau was relatively lower than the tract to the south of the present course of the stream, but that by denuciation the relations have been reversed, whilst the river has never left its originally selected course.

Tile author compares the state of things with that which must have occurred in the case of the northerly rivers running from the centre of the Wealden axis; but mentions that Prof. Safford and Mr. J. Leslie account for the Cumberland plateau by faulting, though he thinks that the well-defined escarpment along the valley of East 'Tennessee seems to show that this cause is insufficient.

In conclusion, he believes that the denudation was accelerated during the pluvial or "Champlain" period, and calls attention to the "Columbia formation" of the east side of the Alleghanies, and to the deposic of red loam by which the surface of the country of the valleys of the Tennessee and Sequachee is overspread, and which is probably referable to a similar stage.

3. "On certain Ornithosaurian and Dinosaurian Remains." By R. Lydekker, Esq., B.A., F.G.S.

VIII. Intelligence and Miscellaneous Articles. EXPERIMENTAX INVESTIGATIONS ON I'HOMSON'S L $\Lambda \mathrm{W}$ OF WAVE-MOTION ON WATER. BY O. RIESS.

THE influence of surface-tension on the wave-motion of water was, as is well known, first theoretically investigated by $\operatorname{Sir} \mathrm{W}$. 
Thomson, and by Kolacek, and expressed by the formula

$$
v^{2}=n^{2} \lambda^{2}=g\left(\frac{\lambda}{2 \pi}+\frac{2 \pi}{\lambda} \mathrm{T}\right) \text {, and } v^{2}=g\left(\frac{\lambda}{2 \pi}+\frac{2 \pi}{\lambda^{2}} \mathrm{~T}\right) .
$$

The velocity of propagation $v$ is thus a function of two forces which are independent of each other-g (gravity) and $\mathrm{T}$ (surface-tension). On the other hand, considered as a function of $\lambda$, it has a minimum, namely 23.11 centim. for the wave-length $\lambda=1.709$ centim.; so that from this there results a natural division of waves into two classes-ripples and large waves. Although observations on ripples have been made by Thomson, Matthiesen, Lord Rayleigh, Arendts, and others, these observations are wanting in the requisite accuracy, and accordingly the author has carried out systematic observations by various methods which control each other. In the first method, tuning-forks were used to produce the waves; in the second, the simultaneous vibration of the armatures of two electromagnets; and finally in the third, which was made on a large scale in the Rostock filtering-basins, small plates which were fixed to rods at the level of the water. Stationary waves were always used, as these are more favourable for observation and for calculation. Reference must be made to the original for the observation of the numbers of vibrations and the wave-lengths in the individual cases, and for the manner in which the numerous difficulties were overcome. As the results of the various meihods are essentially the same, it will be sufficient here to give a summary of that of the first. Five different tuning-forks gave the following results :-

\begin{tabular}{|c|c|c|c|c|c|c|c|}
\hline \multirow{2}{*}{$n}$. & \multicolumn{2}{|c|}{$\lambda$, in centim. } & \multirow{2}{*}{$\Delta \lambda}$. & \multicolumn{2}{|c|}{$v$, calc. in centim. } & \multirow{2}{*}{$\begin{array}{l}\text { Meaul of } \\
\text { one ob- } \\
\text { servation }\end{array}$} & \multirow{2}{*}{$\begin{array}{l}\text { Error of } \\
\text { theresult. }\end{array}$} \\
\hline & Calc. & Obs. & & Thomson! & Obs. & & \\
\hline $8+115$ & 2947 & 2764 & 0.183 & $24 \cdot 80$ & $23 \cdot 26$ & 0.029 & 0.004 \\
\hline $16 \cdot 215$ & $1 \cdot 435$ & $1 \cdot 321$ & 0.114 & 2327 & $21 \cdot 42$ & 0.009 & 0.001 \\
\hline $36 \cdot 677$ & 0.739 & 0.675 & $0 \cdot 064$ & $27 \cdot 10$ & $24: 76$ & 0.020 & 0.009 \\
\hline $37 \cdot 140$ & 0.732 & $0 \cdot 670$ & 0.062 & $27 \cdot 19$ & 24.88 & 0.011 & 0.008 \\
\hline $64 \cdot 635$ & 0.493 & 0.450 & 0.043 & $31 \cdot 87$ & 2909 & 0.005 & 0.000 \\
\hline
\end{tabular}

The calculation of Thomson's results was made by putting

$$
\frac{981 \cdot 4}{6 \pi n^{2}} \sqrt{\frac{1}{3 \pi^{2} \mathrm{~T}}}=\tan \alpha, \quad \sqrt[3]{\tan \frac{\alpha}{2}}=\tan \rho, \lambda=\sqrt{3 \pi^{2} \mathrm{~T}} \tan 2 \beta ;
$$

and from this $\lambda$, and therefore $v$, was calculaced. It will be seen that the experiment agrees sufficiently well with the theory as regards the position of the minimum of $v$, and $o_{-}$the general course of the values of $\lambda$ and $v$; on the other hand, all the observed values are considerably smaller than the calculated ones. In order to follow this more minutely, measurements were made at various 
temperatures (the above hold for $20^{\circ}$ ), and the following result was obtained :-

\begin{tabular}{|r|c|c|c|c|c|c|c|c|c|}
\hline \multicolumn{2}{|c|}{$0^{\circ}}$. & \multicolumn{2}{|c|}{$20^{\circ}}$. & \multicolumn{2}{c|}{$40^{\circ}}$. & \multicolumn{2}{|c|}{$60^{\circ}}$. & \multicolumn{2}{c|}{$80^{\circ}}$. \\
\hline$n$. & $\lambda$. & $n$. & $\lambda$. & $n$. & $\lambda$. & $n$. & $\lambda$. & $n$. & $\lambda$. \\
\hline $8 \cdot 418$ & $2 \cdot 848$ & $8 \cdot 415$ & $2 \cdot 764$ & $8 \cdot 411$ & $2 \cdot 701$ & $8 \cdot 405$ & $2 \cdot 656$ & 8394 & $2 \cdot 628$ \\
$16 \cdot 224$ & $1 \cdot 384$ & $16 \cdot 215$ & $1 \cdot 328$ & & & & & & \\
$36 \cdot 695$ & 0.715 & $36 \cdot 677$ & $0 \cdot 675$ & $36 \cdot 653$ & $0 \cdot 645$ & $36 \cdot 617$ & $0 \cdot 623$ & 36.551 & $0 \cdot 608$ \\
$37 \cdot 160$ & $0 \cdot 709$ & $37 \cdot 140$ & $0 \cdot 670$ & & & & & & \\
$64 \cdot 668$ & $0 \cdot 477$ & $64 \cdot 635$ & $0 \cdot 450$ & $64 \cdot 591$ & $0 \cdot 430$ & $64 \cdot 525$ & $0 \cdot 415$ & $64 \cdot 404$ & $0 \cdot 404$ \\
\hline
\end{tabular}

It is apparent from this that the want of agreement between theory and experiment is to be sought in the dependence of surfacetension on temperature on the one hand, and on the wave-length on the other. If this dependence is eliminated, we get the following values :-

\begin{tabular}{|c|c|c|c|c|c|c|c|c|c|}
\hline$\lambda$. & $\mathrm{T}_{0^{*}}$ & $\lambda$. & $T_{20}$ & $\lambda$. & $\mathrm{T}_{40}$ & $\lambda$. & $\mathrm{T}_{60^{\circ}}$ & $\lambda$. & $\mathrm{T}_{80^{\circ}}$ \\
\hline $2 \cdot 848$ & 0.0600 & 2764 & 0.0490 & $2 \cdot 701$ & 0.0413 & $2 \cdot 656$ & 0.0360 & $2 \cdot 628$ & $0 \cdot 0324$ \\
\hline 0.715 & 0.0669 & $0 \cdot 675$ & 0.0557 & $0 \cdot 645$ & 0.0479 & $0 \cdot 623$ & 0.0429 & $0 \cdot 608$ & 0.0393 \\
\hline 0.477 & 0.0678 & $0 \cdot 450$ & 0.0566 & 0.430 & 00491 & 0.415 & $|0.0439|$ & 0.404 & $0 \cdot 0402$ \\
\hline
\end{tabular}

From this we obtain for $0^{\circ}$ the formula

$$
v^{2}=g\left(\frac{\lambda}{2 \pi}+\frac{2 \pi}{\lambda}\left(0.070-0.0 .411 \lambda^{0.84}\right)\right),
$$

and for various temperatures the formula

$$
v^{2}=g\left(\frac{\lambda}{2 \pi}+\frac{2 \pi}{\lambda}\left(\mathrm{T}_{0}-0 \cdot 0,591 t+0 \cdot 0_{s} 31 t^{2}\right)\right),
$$

in which $T_{0}$ is the expression within brackets of the first formula. This latter value vanishes for $\lambda=28$ centim.; according to Thomson the influence of surface-tension on this wave-length would still be $\mathrm{T}_{0}=0 \cdot 1$ centim., that is about $\frac{1}{3}$ per cent. For an infinitely small $\lambda$ $\mathbf{T}_{0}=0.070$, which agrees sufficiently with the values ordinarily assumed. It may be observed that with other methods the number of vibrations went down to 2.67 and the wave-lengths rose to 21.915, while the $T_{0}$ sank to $0 \cdot 0130$, and that nevertheless the above two formulæ for $v^{2}$ agreed very well. The actual state of the case lies between Kolacek's formula and that of Thomson for $\lambda=1 \cdot 672$ : for instance, according to Thomson $n=13.83$; according to Kolacek, $n=12 \cdot 33$; experiment, $n=13 \cdot 33$.

Phil. Mag. S. 5. Vol. 31. No. 188. Jan. 1891. 
Hence $T$ is proportional neither to $\lambda$ nor to $\lambda^{2}$.-Exner's Repertorium der Physik, xxvi. p. 102 (1890); Beiblätter der Physik, xiv. p. 938.

\section{ON THE CONDENSATION OF AQUEOUS VAYOUR IN CAPILLARY SPACES. BY G. VAN DER MENSBRUGGHE.}

The author propounds the task of furnishing an exact experimental proof of Thomson's theory, that the maximum pressure of aqueous vapour for a given temperature is smaller for a concave surface than for a plane one, and continually decreases with increasing concavity. In the first part of the present research a number of facts are collected which serve as examples for the condensation of aqueous vapour in capillary spaces. Mention is made of the microscopic capillary slits in organic hygroscopic structures, the deposition of ice-flowers on the dusty parts of our window-panes, the phenomenon that particles of iron rust most when they appear protected by materinls, such as cloths, dry wood, and the like, which are in contact with them.

In reference also to Aitken's experiments on the fog-producing uction of suspended particles of dust, the author urges as the explanation the irregular shape and the ultra-capillary cracks of the individual particles. The author observes incidentally, that the rapid rotting of fabrics, such as trille, which are often coated with aqueous vapour even in air which is far from its point of saturation, may be explained by thermoelectric currents which are formed on moistening and on drying (Bull. Ac. Belg. [2] vol. xli. p. 769,1876$)$. The durability of the clothing with which Egyptian mummies are wrapped depends on the filling of the capillary cracks with wax. The author strongly recommends that for the preservation of oil-paintings they should be varnished on the back.-Bull. Ac. Belg. [3] vol, xix. p. 101 (1890); Beiblätter der Physik, No. 11, 1890.

\section{ON FLECTRICAL CONVECTION. BY A. RIGHI.}

In this note the author describes new experiments, which taken in conjunction with those he has previously published appear to him to establish :-

That in all cases in which there is an escape of electricity either by a point, or by an incandescent body, or by a metal exposed to uitra-violet radiations, the phenomenon is due to convection; and that the particles in movement follow sensibly the lines of force of the field in which they move. In more or less rarefied air the trajectories seem to diverge more and more from the lines of force; and in the case of an extreme degree of rarefaction they should become almost rectilinear, as appears to be the case with the particles of radiant matter in Crookes's tubes.

The autbor proposes to make experiments to see if this gradual 